\title{
Gasometric method of volume determination of intercellular spaces in plant tissues
}

\author{
J. CZERSKI
}

\section{INTRODUCTION}

The size of intercellular spaces, their distribution in plant organs, structure, mode of formation and gas composition have been the subject of many studies. On the compactness of plant tissues depends the internal gas composition, and this in its turn has an effect upon many essential processes such as respiration and photosynthesis.

The function performed by intercellular spaces is particularly easy to observe in plants growing on substrate which periodically or permanently exhibit oxygen deficiency. By producing a ventilating system of suitable size, plants in such are as protect themselves against the adverse effects of anaerobic soil conditions. The large air chambers and channels in aquatic plants not only create favourable conditions for gas exchange in the whole plant but also by lowering its specific gravity, are instrumental in keeping the plant upright in water.

As early as 1854 Un g e r made a study of the air content of intercellular spaces. Stahl (1894) called attention to the importance for transpiration of the internal leaf surface area. Neger (1918), using an infiltration method determined the size of air chambers in one-year old and older plants. From the course of the infiltration, he ascertained which leaves are provided with heterobaric chambers and which, with homobaric. Many investigations on the dependence of the degree of development of the ventilating system on light conditions and the leaf structure and size, were carried out by $\mathrm{Turell}(1936,1942,1944)$. According to the results obtained by that author, the size of intercellular spaces is not a stable feature but is subject to considerable fluctuations upon which an influence is exerted by enviromental agencies. Roguska (1957) and Roguska-Wasilewska (1960) studied the effect of soil moisture on the size of intercellular spaces in Festuca and Poa. According to her findings, the underground plant parts react to oxygen deficiency more strongly, by expansion of intercellular spaces, than the aearial parts. Conway (1937) has investigated the capacity for gas transfer from leaves to roots in Cladium mariscus $\mathrm{R}$. Br. That author has established that roots growing in silt 
are supplied with oxygen through the base of dead or green leaves which have already completed growth.

Most of the hitherto used methods for volume determination of intercellular spaces are based on the method of Ung er (1854), the principle of which depends on the determination of the weight of water that penetrates the intercellular spaces in place of gases removed by vacuum. A modification of this method was worked out by Froeschel (1951) who applied hydrostatic pressure to infiltrate the tissue with water. Air may be also removed from the tissue by centrifugation. The measurement of the size of intercellular spaces in tissues difficult to infiltrate are performed with the aid of a microscope.

When methods of infiltration are used, the following factors affect the degree of filling of the intercellular spaces:

1. Degree of stomata opening and their distribution frequency. The changing size of the stomatal aperture frequently restricts the measurement possibilities.

2. Turgor pressure in the tissue investigated. Low turgor pressure in the plant tissue examined prevents from obtaining correct results. If the material under investigation shows suction pressure, water will not only fill the intercellular spaces but also will be taken up by the cells.

3. Difficulty in determining the completion of the infiltration process. In reflected light, the infiltrated green tissues of a plant appear dark-green, whereas in transmitted light they appear light-green; the reverse is true for unifiltrated tissues. The use of this simple criterion is impossible when dealing with thick tissues, or with those devoid of chlorophyll such as tubers or roots.

4. Drying of the infiltrated material. Water can be completly removed from the surface of an organ provided it is not crinkled or tomentose.

5. Evaporation of water from the intercellular spaces.

The object of the present work was to elaborate a method for volume determination of intercellular spaces, which would permit the minimization of the above-mentioned surces of errors.

\section{RESEARCH METHOD}

\section{Description of the apparatus}

Basically the operation of the apparatus depends on the formation of a vacuum in extraction vessels $A$ and $A_{1}$ by means of an oil pump so as to obtain gas samples, the volume of which is measured in a capillary tube $K$.

The apparatus (Fig. 1) is made of Jena glass and is composed of two identical extraction vessels $A$ and $A_{1}$ connected by means of tubes I, 
together with a centrally situated measuring capillary $K$. The capillary tube, $1 \mathrm{ml}$ in capacity and greaded into 500 parts, is placed in a water jacket $P$ provided with a termometer. Pear-shaped bulb $\mathrm{G}$ containing freshly boiled and cooled distilled water serves to fill the extractors and the connecting tubes. It enables the transfer of the obtained gas to the capillary and subsequently to remove it outside the assembly. The component parts of the apparatus are connected with heavy-walled but flexible pressure tubing. Each extractor consists of an outer vessel $Z$ provided with a stop-cock $R$, with a ground glass stopper $S$ closing its upper part and with a ruber stopper $O$, and of an inner cylinder $C$

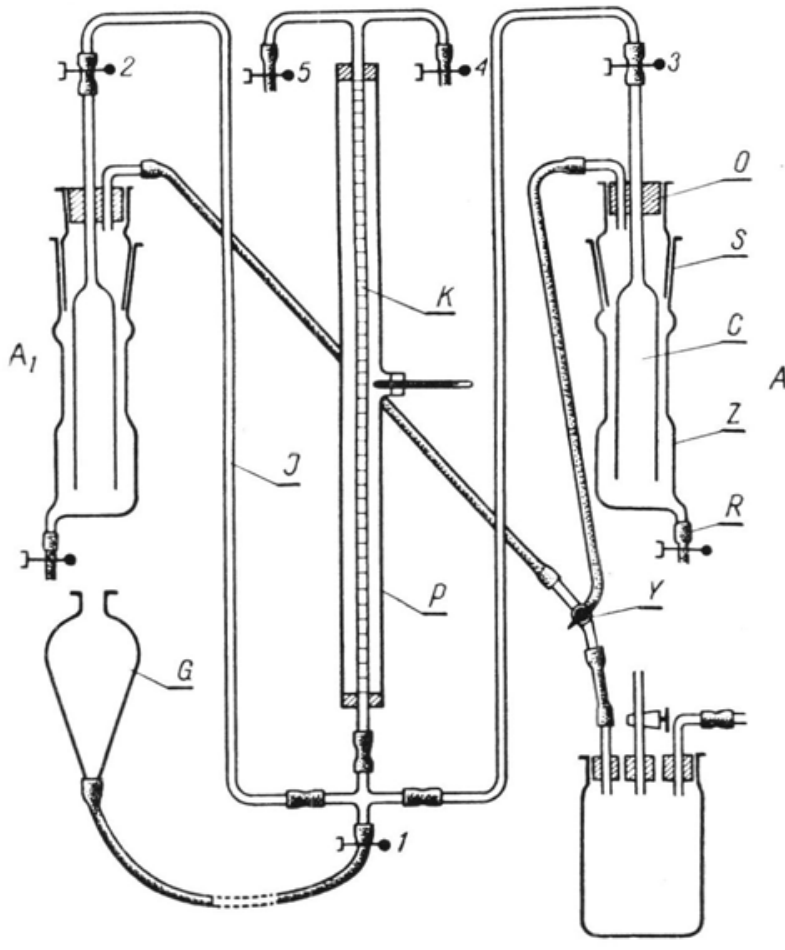

Fig. 1. Apparatus for extraction of gases from plant tissues.

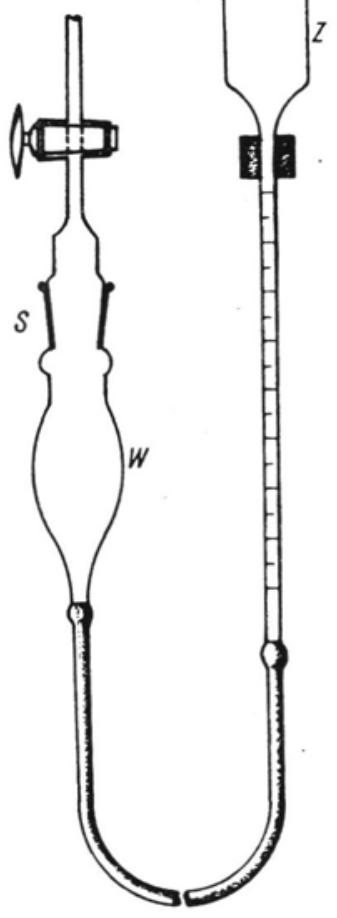

Fig. 2. Apparatus for measurement of volume of material investigated.

(open at the bottom) fixed in the stopper $\mathrm{O}$ and connected through it with the outer parts of the arrangement by a glass tube.

The volume of the organ examined was measured in the glass assembly presented in Fig. 2. This assembly comprises two vessels $Z$ and $W$ connected with pressure tubing. The vessel $W$ is filled up to the stop-cock of the stopper $S$ (but not higher), with distilled water and then 
after a minute the water level in the ibottom section of the capillary of vessel $Z$ is recorded. Next the stop-cock of stopper $S$ is closed, the vessel $Z$ lowered so that the vessel $\mathrm{W}$ becomes partially evacuated, then investigated plant organ is placed in vessel $W$ and it is refilled with water as previously. The water level in the capillary is recorded once again and the volume of the investigated organ is obtained from the difference between the two readings.

The capillary tube used in this work was $3,5 \mathrm{~cm}^{3}$ in capacity and was graded to read $0,01 \mathrm{~cm}^{3}$.

\section{MEASUREMENT TECHNIQUE}

Before measurement, cylinder $C$ is filled with water by raising the bulb $G$ to a suitable level and releasing the clamps 1 and 2. Having filled the air space between the wall of cylinder $C$ and vessel $Z$, the three-way cock $Y$ is connected with a rubber pear through and by creating a pressure, water is driven to cylinder $C$ and to otrer sections of the apparatus. Identical procedure is used to fill the second extractor. Excess water is run off through drain cocks $R$ till the water level half fills the vessel $Z$. Then the three-way cock $Y$ is connected with the vacuum oil pump in order to remove air from the water. When the vacuum pump is switched off and the pressure inside the apparatus equalized with the atmospheric pressure, the gas exuided collects in the upper section of the cylinders from where it is removed to the outside by setting bulb $G$ at a required level and releasing clamp 2 for extractor $A_{1}$ and clamp 3 for extractor $A$. Water will be assumed air-free if following a one-hour extraction of gases, an additional 15-minute extraction will result in the liberation of no more than a few cub. $\mathrm{mm}$ of gas from each extractor.

After deaeration of the water a previously measured volume of the plant material under investigation is placed in the cylinders and the assembly is filled with water. As soon as vacuum pump is connected to the extractor, gas bubbles begin to come out from the plant organ. The extraction time is one minute. After the pressure in the apparatus reaches equilibrium with atmospheric, the gas which has gathered in the upper narrow part of cylinder $C$ is moved to capillary $K$ in the following manner. Clamps 1 and 2 are released and bulb $G$ placed at such a level as to make the gas move from extractor $A_{1}$ to the bottom section of the measuring capillary. After closing clamps 1 and 2, clamp 4 or 5 is released and by raising the bulb $G$ and slightly releasing clamp 1 the gas is brought to zero position in the capillary. The volume of the collected gas is read while the outlet clamp 4 or 5 is off. The gas liberated in the second extractor is measured in an identical manner. The measured volume of gas comprises from intercellular spaces and water vapour. 
Since the water-vapour tension in intercellular spaces is approximately the same as that in the capillary, no correction for it volume is necessary. The practically identical temperature and gas pressure in the intercellular spaces and in the capillary eliminate the need for converting the volume readings of gas to normal conditions.

\section{EXPERIMENTAL PART}

As previously noted, the method described consists of the measurement of the gas evolved from the plant tissue examined. Due to the reduction of pressure, not only the free gas is liberated from intercellular spaces but also the gas dissolved in the cell fluids. Consequently, for determining the volume of intercellular spaces, it was essential to choose such an extraction period as to permit the fullest liberation of gases contained in the intercellular spaces together with a minimum amount of gas derived from the solution. This requirement is not difficult to fulfill as will be shown below. The necessary results were obtained by comparing the volumes of the gas with the volume of water infiltrating the leaf. For measurement the leaves of Syringa vulgaris (L.) were used. The results are presented in Fig. 3. After one-minute extraction in a vacuum of $30 \mathrm{~mm} \mathrm{Hg}, 300 \mathrm{~mm}^{3}$ of gas were

Fig. 3. Comparison of volume of leaf-infiltrating water with gas volume obtained after one-minute extraction in Syringa vulgaris L. 1-Water volume, 2 - Gas volume.

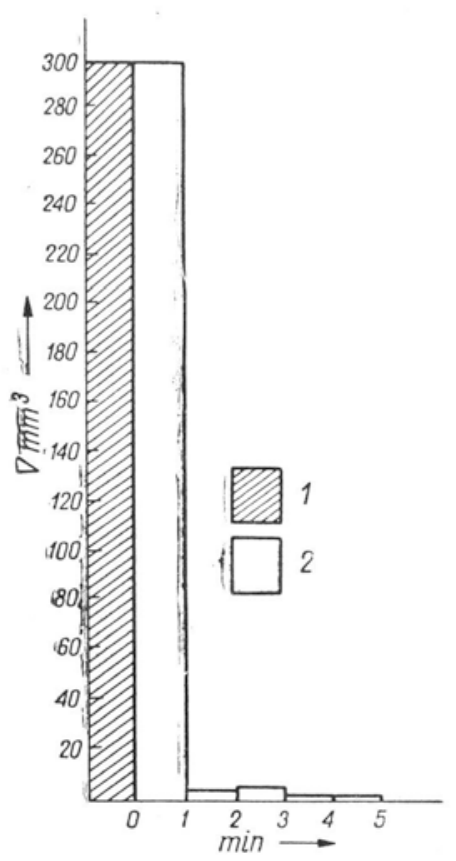

obtained. In the following four one-minute extractions, 4, 5, 2 and $2 \mathrm{~mm}^{3}$ gas were registered. The weight of water infiltrating the leaf converted to volume was equal to $300 \mathrm{~mm}^{3}$, it was therefore exactly the same as the volume of gases obtained after one-minute extraction. Further liberation of gas $\left(13 \mathrm{~mm}^{3}\right)$ had no effect on the weight of water of infiltration, which indicates that this gas was not derived from intercellular spaces. The experiments on the course of gas extraction from distilled water in the 
extractors (Fig. 4) made it possible to establish an extraction curve, the character of which is very similar to the sector of the curve obtained after one-minute gas extraction from the tissue (Fig. 3). This substantiates the conclusion that the additional amounts of gas liberated after the first minute of extraction originate from deaeration of the cell liquids, and to some extent, from respiration of the tissue.

It has been found that when such material as Deutzia leaves is used, extending the extraction or repeating it for a prolonged period after infiltration of the leaf, results in the liberation of additional and considerable amounts of gases. The extra amounts of gas obtained during the prolonged extraction come from the liberation of gas from the water system surrounding the examined material. This liberation is probably caused by a catalitic effect arising from the specific structure of leaves. Despite the catalitic acceleration of additional gas liberation, the gas is removed from the liquid only after a considerable time period as compared with that required for gas extraction from the intercellular spaces. Therefore the amount of gas obtained during the first minute of extraction and corresponding to the volume of the intercellular spaces,
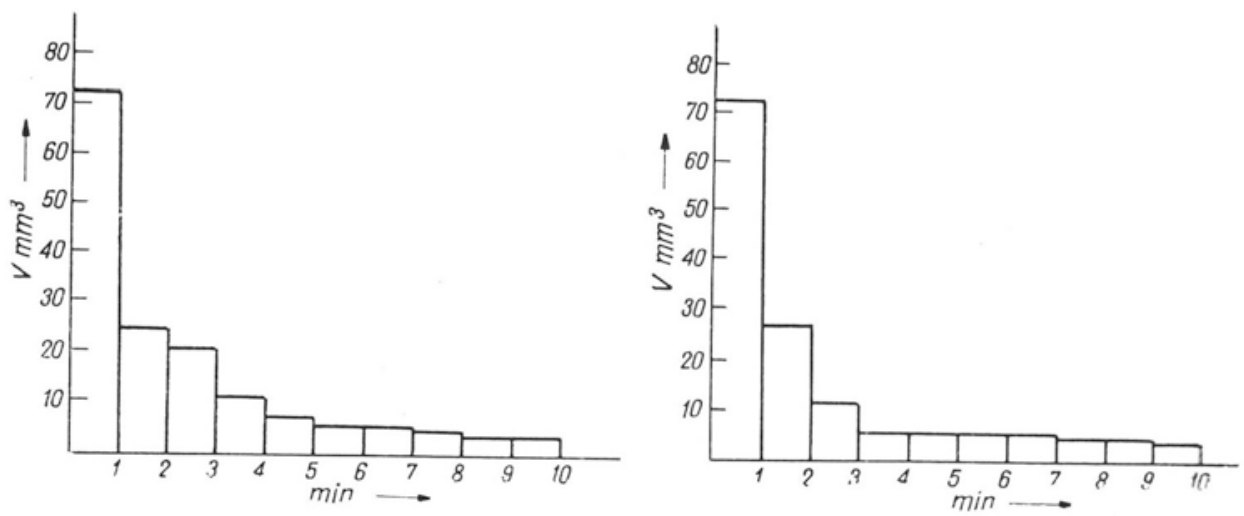

Fig. 4. Course of extraction of gases from distilled water.

as can be seen in Table 1, is unaffected. During the following two 15-minute extractions, the additional amounts of gas obtained were the outcome of liberation of gas from water. The fact that the gas from the second and third extraction originated from water was also confirmed by the absence of further water infiltration of the intercellular spaces, which would take place if the gases originated from the leaf tissue.

Further measurements on Syringa vulgaris leaves with the use of both methods are presented in Table 2. The results obtained give 
Table 1

Catalytic effect of Deutzia scabra (Thunb.) leaves on extra exudation of gas from water during second and third 15-minute extraction

\begin{tabular}{c|c|c|c}
\hline $\begin{array}{c}\text { One-minute } \\
\text { extraction } \\
\text { V gas in } \mathrm{mm}^{3}\end{array}$ & $\begin{array}{c}\text { V of infiltrating } \\
\text { leaf water } \\
\text { in } \mathrm{mm}^{3}\end{array}$ & \multicolumn{2}{|c}{$\begin{array}{c}\text { 15-minute extraction } \\
\text { V gas in } \mathrm{mm}^{3}\end{array}$} \\
\hline I & & II & III \\
\hline 120 & 118.3 & 122 & 62 \\
190 & 185.3 & 138 & 64 \\
184 & 176.6 & 104 & 60 \\
180 & 185.5 & 180 & 126 \\
182 & 168.9 & 224 & 150 \\
188 & 170.8 & 244 & 138 \\
158 & 155.0 & 214 & 114 \\
172 & 156.0 & 210 & 110 \\
174 & 166.8 & 234 & 82 \\
142 & 142.7 & 202 & 138 \\
\hline
\end{tabular}

evidence that one minute is a sufficient time for extraction in order to secure a complete expulsion of gas from the intercellular spaces. The intercellular spaces as percentage of tissue volume calculated with the aid of gasometric and infiltration methods give consistent results, and the slightly higher values obtained by the infiltration method in individual measurements, may be due to incomplete turgor of the leaves examined.

The amount of gas obtained at a specified pressure characterizes the volume of intercellular spaces, but does not account for the full volume because some of the gas remains unremoved. The remainder left in intercellular spaces was calculated from an equation which takes into account the pressure used and the actual atmospheric pressure.

$$
X=\frac{V_{0} p_{1}}{p_{2}-p_{1}}
$$

where $X=$ residual amount of gas in intercellular spaces

$V_{0}=$ volume of gas obtained

$p_{1}=$ pressure used in $\mathrm{mm} \mathrm{Hg}$

$p_{2}=$ atmospheric pressure in $\mathrm{mm} \mathrm{Hg}$

The figures specified in the last column of Table 2 give the real values for the volume of intercellular spaces after correcting for atmospheric pressure and the pressure used for evacuation.

Further comparative measurements were made on leaves of the following plants: Deutzia scabra Thumb., Ginkgo biloba Linn., Fagus 
Table 2

Volume of intercellular spaces of Syringa vulgaris L. leaves in terms of percentage, determined by the method of vacuum infiltration and the gasometric method

\begin{tabular}{|c|c|c|c|c|c|c|}
\hline \multirow[b]{2}{*}{$\begin{array}{l}\text { Weight of } \\
\text { leaf in } g\end{array}$} & \multirow[b]{2}{*}{$\begin{array}{l}\text { Volume of } \\
\text { leaf in } \mathrm{cm}^{3}\end{array}$} & \multirow{2}{*}{$\begin{array}{l}\text { Volume of } \\
\text { gas after } \\
\text { one-minute } \\
\text { extraction } \\
\text { in } \mathrm{cm}^{3}\end{array}$} & \multirow[b]{2}{*}{$\begin{array}{c}\text { Volume of } \\
\text { infiltration } \\
\text { water in } \mathrm{cm}^{3}\end{array}$} & \multicolumn{3}{|c|}{ Volume of intercellular spaces $\%$} \\
\hline & & & & $\begin{array}{l}\text { infiltration } \\
\text { method }\end{array}$ & $\begin{array}{c}\text { gasometric } \\
\text { method }\end{array}$ & $\begin{array}{l}\text { result after } \\
\text { correction }\end{array}$ \\
\hline 1.3625 & 1.41 & 0.218 & 0.2231 & 15.8 & 15.4 & 16.2 \\
\hline 0.8928 & 0.93 & 0.150 & 0.1498 & 16.1 & 16.1 & 16.9 \\
\hline 1.1749 & 1.24 & 0.184 & 0.1859 & 14.9 & 14.8 & 15.4 \\
\hline 0.7959 & 0.83 & 0.128 & 0.1257 & 15.1 & 15.4 & 16.0 \\
\hline 0.7495 & 0.76 & 0.114 & 0.1248 & 16.4 & 15.0 & 15.7 \\
\hline 0.6366 & 0.68 & 0.106 & 0.1083 & 16.9 & 15.5 & 16.2 \\
\hline 0.6234 & 0.69 & 0.116 & 0.1099 & 15.9 & 16.8 & 17.4 \\
\hline 0.9905 & 1.00 & 0.160 & 0.1632 & 16.3 & 16.0 & 16.6 \\
\hline 1.0122 & 1.03 & 0.166 & 0.1652 & 16.0 & 16.1 & 16.8 \\
\hline \multirow[t]{2}{*}{1.4500} & 1.54 & 0.236 & 0.2514 & 16.3 & 15.3 & 15.9 \\
\hline & & & Average & 15.9 & 15.6 & 16.3 \\
\hline
\end{tabular}

silvatica L. and Nerium oleander L. The average values for ten readings made for each type of leaves are presented in Table 3.

Both in Deutzia and Ginko leaves, infiltration began as soon as an equilibrium had been established between the pressures inside the apparatus and the atmospheric pressure. The figures obtained for the two methods, were comparable. The Nerium and Fagus leaves were the hardest to infiltrate, and the intercellular-spaces were filled only after about 20 hours. After such an infiltration period in the case of Nerium oleander leaves the same values for the volume of intercellular spaces were obtained by the two methods, whereas in Fagus silvatica, the results differed.

The volumes of intercellular spaces obtained by the gasometric method were generally higher for leaves difficult to infiltrate. This seems to have been due to incomplete infiltration. Visually, no "empty" spaces could be ascertained, which suggests that this phenomenon affected intercellular spaces situated in deeper layers of the tissue.

Extraction of gas from a plant tissue was found to take place much faster than penetration of water in its place, and this could be readily observed, especially with regard to beech and oleander leaves. Only the extraction of gases from succulent plants having scarce and tightly closing stomata may proceed with difficulty. The experiments made on leaves of Crassula multicava Lem. which is a succulent plant, revealed 
Table 3

Volume of intercellular space of leaves in four plant species (average value for ten readings) determined by the method of infiltration and the gasometric method

\begin{tabular}{l|c|c|l}
\hline \multirow{2}{*}{ Plant species } & \multicolumn{2}{|c|}{$\begin{array}{l}\text { Volume of intercellular spaces } \\
\%\end{array}$} & \multirow{2}{*}{. Infiltration period } \\
\cline { 2 - 3 } & $\begin{array}{c}\text { gasometric } \\
\text { method }\end{array}$ & $\begin{array}{c}\text { infiltration } \\
\text { method }\end{array}$ & \\
\hline Deutzia scabra Thunb. & 28.8 & 26.7 & approx. 2 minute \\
Ginkgo biloba Linn. & 27.6 & 27.2 & approx. minute \\
Fagus silvatica L. & 20.6 & 16.5 & approx. 20 hours \\
Nerium oleander L. & 23.37 & 23.08 & approx. 20 hours \\
\hline
\end{tabular}

Table 4

The effect of pinholes in Crassula multicava Lem. leaves on the result of volumetric measurement of gas in intercellular spaces at 3- and 1-minute extraction

\begin{tabular}{c|c|c|c|c}
\hline \multirow{2}{*}{ Weight of leaf in $\mathrm{g}$} & \multicolumn{2}{|c|}{ I 3-minute extraction } & \multicolumn{2}{c}{$\begin{array}{c}\text { II 1-minute extraction } \\
\text { (pinholed leaf) }\end{array}$} \\
\cline { 2 - 4 } & $\begin{array}{c}\text { gas volume } \\
\text { in } \mathrm{mm}^{3}\end{array}$ & $\begin{array}{c}\text { water volume } \\
\text { in } \mathrm{mm}^{3}\end{array}$ & $\begin{array}{c}\text { gas volume } \\
\text { in } \mathrm{mm}^{3}\end{array}$ & $\begin{array}{c}\text { water volume } \\
\text { in } \mathrm{mm}^{3}\end{array}$ \\
\hline & & & & 225 \\
1.350 & 146 & 40 & 106 & 285 \\
1.570 & 156 & 30 & 122 & 300 \\
1.320 & 116 & 5 & 108 & 270 \\
1.530 & 140 & 30 & 110 & 195 \\
\hline
\end{tabular}

that pinholes made in the leaf at a dozen odd places are absolutely sufficient to ensure a complete exudation of gas from intercellular spaces during a one-minute extraction. The removal of gas from the leaf with no pinholes requires a three-minute extraction and on the average only $80 \mathrm{~mm}^{3}$ of gas per $1 \mathrm{~g}$ tissue is obtained as against $83 \mathrm{~mm}^{3}$ for pinholed leaves after one-minute extraction. The results of three-minute extraction of gas from Crassula multicava leaves with no pinholes and of one-minute extraction from pinholed leaves, are presented in Table. 4. The experiment was carried out as follows: after weighing, the leaves were subjected to a three-minute extraction, then they were weighed again and after pinholes had been made extraction was resumed for another one minute. The volume of gas obtained from the second extraction was reduced by the volume of water which infiltrated intercellular spaces during the first extraction. 
The volume of water that infiltrated the tissue during two extractions is considerably in excess of the volume of gases obtained, which is caused by the presence of considerable amounts of hydrophilic compounds in the cells of succulent plants.

A ubert (1892) in his reasearch on respiration and photosynthesis of succulent plants has incorrectly assumed that the volume of intercellular spaces is equal to the amount of water penetrating them. As a result he obtained unduly high values for intercellular spaces of Crassula arborescens leaves more than $300 \mathrm{~mm}^{3}$ per $1 \mathrm{gm}$ of fresh weight.

In order to examine the effect of the degree of tissue saturation with water upon the results of volume measurement of the intercellular spaces by both methods an experiment was carried out. S. vulgaris leaves owing to their ability for quick and complete infiltration, were used for this purpose. Having determined the amount of gas exuded and the amount of water that filled the intercellular spaces, the leaf was allowed to dry in air until it reduced its weigth to the original value. In this condition, the leaf gave optically a picture devoid of infiltration water both in reflected and absorbed light. Then the leaf was subjected once again to extraction in vacuum and after measuring the volume of gas, the leaf was infiltrated for a second time. The results are given in Table 5. The results of experiments 1 and 2 show that after the first infiltration, the volume of the gas obtained exactly corresponds to the volume of infiltrated water. After the second infiltration, the same amount of infiltrated water was obtained while the amount of liberated gas decreased.

Experiments 3 and 4 were made with leaves, the weight of which after the first infiltration was reduced below the original by means of a prolonged transpiration period. The amounts of gas obtained in the two successive extractions were the same whereas the weight of water that infiltrated the leaf was higher in the second infiltration by an amount corresponding to the weight of water lost by the leaf during transpiration.

Experiments 5 and 6 differed from the previous ones in that leaves not entirely deprived of infiltration water were used for the second infiltration, that is they had a weight above the initial one. The volume of the gas obtained in the first extraction, both in experiment 5 and 6 was equal to the volume of infiltrated water. In the second extraction (experiment 5), less gas than the volume of infiltrated water was obtained, and in experiment 6, nearly identical amounts of water and gas were recorded. 
The measurement of the volume of intercellular spaces in Syringa vulgaris leaves having different water contents (Table 5) revealed the following facts:

a. The differences between the amount of gas obtained and the amount of infiltrated water after the second infiltration (experiments 1 and 2) must be explained by an unequal rate of transpiration of different parts of the leaf. The weight of leaf obtained after the first infiltration was equal to the original one, but is the result of a partial loss of water from intercellular spaces and also from the leaf cells themselves. The amount of water which infiltrated the leaf after the first and second infiltration is the same but its distribution is different.

In the first case, the water penetrating the leaf fills intercellular spaces, as confirmed by the fact that the volume of extracted gas corresponded to the volume of infiltrated water. In the second case, the infiltrated water fills not only the intercellular spaces partially devoid of water but also complets the water losses of the cells.

Table 5

The effect of water content of Syringa vulgaris L. leaves on the results of volumetric measurement of intercellular spaces by the infiltration method and the gasometric method

\begin{tabular}{|c|c|c|c|c|}
\hline $\begin{array}{c}\text { Experi- } \\
\text { ment } \\
\text { Number }\end{array}$ & $\begin{array}{l}\text { Order of extraction } \\
\text { and infiltration }\end{array}$ & $\begin{array}{l}\text { Weight of leaf } \\
\text { in } \mathrm{mg}\end{array}$ & $\begin{array}{c}\text { Volume of infiltration } \\
\text { water in } \mathrm{mm}^{3}\end{array}$ & $\begin{array}{l}\text { Gas volume } \\
\text { in } \mathrm{mm}^{3}\end{array}$ \\
\hline \multirow{3}{*}{1} & 1 & 1470 & 270 & 271 \\
\hline & 2 & 1470 & 270 & 255 \\
\hline & Difference & 0 & 0 & -16 \\
\hline \multirow{3}{*}{2} & 1 & 1420 & 330 & 331 \\
\hline & 2 & 1420 & 330 & 298 \\
\hline & Difference & 0 & 0 & -33 \\
\hline \multirow{3}{*}{3} & 1 & 920 & 220 & 220 \\
\hline & 2 & 815 & 325 & 220 \\
\hline & Difference & -105 & +105 & 0 \\
\hline \multirow{3}{*}{4} & 1 & 1725 & 370 & 370 \\
\hline & 2 & 1670 & 420 & 370 \\
\hline & Difference & -55 & +50 & 0 \\
\hline \multirow{3}{*}{5} & 1 & 1440 & 290 & 292 \\
\hline & 2 & 1460 & 270 & 238 \\
\hline & Difference & +20 & -20 & -54 \\
\hline \multirow{3}{*}{6} & 1 & 806 & 170 & 170 \\
\hline & 2 & 860 & 116 & 112 \\
\hline & Difference & +54 & -54 & -58 \\
\hline
\end{tabular}


Consequently the amount of gas obtained is reduced by the amount of water that had remained in the intercellular spaces. The danger of relying on visual and weight estimates whenever the presence of

Table 6

Percent volume of intercellular spaces of leaves in plants from different enviroment, determined by gasometric method

\begin{tabular}{l|c}
\hline \multicolumn{1}{c|}{ Plant species } & $\begin{array}{c}\text { Volume of intercellular } \\
\text { spaces \% }\end{array}$ \\
\hline Calla palustris L. & $57.7 \pm 1.3$ \\
Limnanthemum nymphoides Link. & $47.4 \pm 2.1$ \\
Menyanthes trifoliata L. & $42.9 \pm 1.8$ \\
Malva silvestris L. & $35.1 \pm 2.4$ \\
Nerium oleander L. & $27.45 \pm 1.9$ \\
Deutzia scabra Thunb. & $29.3 \pm 2.0$ \\
Ginkgo biloba Linn. & $28.8 \pm 3.1$ \\
Symphoricarpos albus L. & $23.5 \pm 5.5$ \\
Pinus silvestris L. & $18.9 \pm 2.0$ \\
Coleus sp. Lour. & $14.6 \pm 3.7$ \\
Begonia heracleifolia Cham. et Schlecht. & $13.8 \pm 3.9$ \\
Peperomia incana A. Dietr. & $12.4 \pm 2.7$ \\
Crassula lactea (Soland in) Ait. Hort. Kew. & $8.1 \pm 2.9$ \\
Crassula multicava Lem. & $7.4 \pm 2.0$ \\
\hline
\end{tabular}

The results are an average for ten readings.

residual water in the intercellular spaces is established, as confirmed by the above-mentioned experiment, explains the differences in readings for the volume of intercellular spaces in Fagus silvatica leaves between the gasometric and the vacuum infiltration methods.

b. Water deficit of the leaf tissue produced before the second infiltration (experiments 3 and 4) guaranteed an absolute removal of water from the intercellular spaces and consequently made it possible to obtain identical amounts of gas in the first and second extraction. Incomplete turgor of the leaf tissue had no effect on the amount of gas obtained, and consequently the results when using the gasometric method were correct, whilst the method of vacuum infiltration proved altogether inapplicable here.

c. Experiments 5 and 6 indicate that transpiration of water from intercellular spaces after the first infiltration did not proceed identically in both cases. Amounts of water penetrating the leaf were bigger than the amounts of gas liberated during the second extraction (experiment 5) indicating that a loss of water partially from intercellular spaces and partially from cells took place. The almost identical amounts of gas 
liberated and of water infiltrated in the second extraction (experiments 6) indicate that in the course of transpiration the water lost came from the intercellular spaces only.

Volumetric determinations of intercellular spaces in leaves of plants belonging to different ecological groups were made exclusively by the gasometric method described above. It was not possible to use the method of vacuum infiltration for the purpose of comparison due to the different anatomic structures of the leaves and their different chemical compositions. The gases were extracted for one minute in a vacuum of $30 \mathrm{~mm} \mathrm{Hg}$.

In Table 6 percentage volumes of intercellular spaces, avarages for ten readings for each species, are given. As anticipated, the greatest volumens of intercellular spaces were found in plants from water and marshy enviroments, and the smallest, in the leaves of succulent plants.

\section{DISCUSSION}

Volumetric measurement of intercellular spaces with the aid of the gasometric method described, consists of the extraction of gas enclosed in the intercellular spaces and determination of its volume. The use of this method makes it possible to eliminate errors connected with the method of vacuum infiltration previously discussed.

However, the gas liberated from the tissue under vacuum is not exclusively of intercellular origin but contains also a portion of the gas dissolved in the liquid phase of the tissue.

It may be assumed that liberation of gas from the liquid phase of the tissue under vacuum conditions will proceed in a manner similar to liberation of gas from water (Fig. 4). After de-aeration of distilled water, previously at equilibrium with the surrounding atmosphere, barely $74 \mathrm{~mm}^{3}$ of gas was obtained during a one-minute extraction from approx $40 \mathrm{ml}$ or water filling the extraction cylinders. This amount is eleven times less than the total volume of gas $\left(832 \mathrm{~mm}^{3}\right)$ dissolved in the same volume of water. Assuming after Burton that the solubility of nitrogen and oxygen in cells is equal to 86 percent of the solubility of these gases in water, $1.4 \mathrm{~mm}^{3}$ of gas will be exuded from a tissue containing $1 \mathrm{~cm}^{3}$ of water during a one minute extraction, this amount considering the total amount of free gas in intercellular spaces, is insignificant and may be neglected.

Experiments 3 and 4 (Table 5) made on Syringa vulgaris leaves with no turgor show that a loss of water amounting to over 11 per cent (in terms of fresh weight) does not affect the results when the gasometric method is used. On the other hand the use of the method of 
vacuum infiltration is inapplicable in this case. As has been demonstrated, a plant tissue, not in a state of full turgor, takes up water in the course of infiltration not only into intercellular spaces but also completes the water deficiency in the cells.

Having established the volume of infiltrated water and of the gases in intercellular spaces, the amount of water deficit of the tissue will be readily determined from the difference.

A more detailed discussion of this problem calls for further studies in this direction.

The presented method as compared with those currently in use features a facility of measurement within a considerably shorter period of time. The determination of the volume of intercellular spaces of leaves difficult to infiltrate requires about 20 hours when the method of infiltration is used. In the case of the gasometric method the measurement can be carried out within a few minutes.

As demonstrated in Table 6, the gasometric method is superior to other methods due to the fact that its application is not restricted by the anatomic structure of leaves and by the hydrophilic substances they contain.

An optical determination whether intercellular spaces have been completely filled with the infiltrating liquid is a prerequisite of an accurate measurement by the infiltration method.

As demonstrated this criterion is inadequate even in the case of chlorophyllic tissues. Using the gasometric method it is not necessary for the measurement to fill the intercellular spaces with liquid, and consequently examination of organs containing no chlorophyll such as roots, tubers and others is made possible.

\section{CONCLUSIONS}

1. A gasomeric method for volume determination of intercellular spaces was elaborated, making possible to avoid errors inherent in the application of the hitherto known methods.

2. The absence of full turgor in plant tissues does not affect the result of measurement of the volume of the intercellular spaces when using the method described.

3. The apparatus devised enable execution of a simultaneous measurement of the volume of intercellular spaces by the gasometric and vacuum infiltration methods.

4. The gasometric method permits measurement of the volume of intercellular spaces of tissues containing large amounts of hydrophilic compounds. 
5. When examining tissues not at full turgor, the volumetric determination of infiltrated water and of gas liberated makes it possible to determine the amount of water deficit in the tissue. It can be calculated from the difference in volume between the infiltrated water and the liberated gas.

Department of Plant Physiology

(Entered: 12.IX.1963)

University of Warsaw

\section{REFERENCES}

A u bert M. E., 1892, Recherches sur la respiration et l'assimilation des plantes grasses, Revue Gén. de Botanique 4:273-282.

Burton W. G., Sprag g W. T., 1950, A note of the intracellular space of the potato tuber, The New Physiologist, 49:8-10.

Burton W. G., 1950, Studies on the dormancy and sprouting of potatoes. I. The oxygen content of the potato tuber, The New Phytologist. 49:121-134.

C o n w a y V. M., 1937, Studies in the autecology of Cladium mariscus R. Br. Par III. The aeration of the subterranean part of plant. The New Phytologist. $36: 64-96$.

Froeschel P., 1951, Neue Methoden der Blattinfiltration, La Cellule 54: $219-231$.

Froeschel P., Chapman Ph., 1951, A new method of measuring the size of the stomatal apertures, La Cellule 54:235-249.

N e g e r F. W., 1918, Die Wegsamkeit der Laublätter für Gase, Flora 11:152-161.

R o g u ska L., 1957, The effect of the variable factor of soil moisture on the size of intercellular spaces of leaves in Poa pratensis L. population, Ekologia Polska B, 3:223-230.

Roguska-Wasilewska L., 1960, Morpho-physiological reaction (size of intercellular spaces of leaves, roots in two ecological files of grass species to water conditions, Ekologia Polska, B, 4:25-33.

S t a h 1 E., 1894, Ưber den Einfluss der Lichtintensität auf Structur und Anordnung des Assimilationsporenchyms, Bot. Ztg. 38.

T u rell F., 1936, Internal surface of exposed leaves of dicotyledones, Mer. Jour. of Bot. 23:255.

Turell F., 1942, A quantitative morphological analysis of large and small leaves of alfa-alfa, with special reference to internal surface, Amer. Jour. of Bot. 29:400.

Ture 11 F., 1944, Correlation between internal surface and transpiration rat of mesomorphic and xeromorphic leaves grown under artificial light, Bot. Gaz. $105: 413-425$.

Unger F., 1854, Beiträge zur Physiologie der Pflanzen. I. Bestimmung der in den Interzellulargängen der Pflanzen enthaltenen Luftmenge. Kön. Akad. Wiss. Math-Natur. 12:367-378. 


\section{Gazometryczna metoda oznaczania objętości przestworów międzykomórkowych tkanek roślinnych}

\section{Streszczenie}

Opracowano gazometryczną metodę oznaczania objętości przestworów międzykomórkowych tkanek roślinnych. Zasada działania skonstruowanego aparatu sprowadza się do usunięcia przy użyciu pompy olejowej gazu zawartego w przestworach międzykomórkowych i do zmierzenia jego objętości. Metoda ta pozwala na uniknięcie błędów wynikających ze stosowania dotychczas znanych metod oraz umożliwia wykonanie pomiaru w czasie kilku minut. Brak pełnego turgoru oraz występowanie znacznych ilości związków hydrofilowych w badanym materiale roślinnym nie wpływa na wynik pomiaru. Przy badaniu tkanek nie będących w pełnym turgorze, oznaczenie objętości wnikającej wody oraz ekstrahowanego gazu umożliwia oznaczenie stanu deficytu wodnego tkanki. Wyliczyć to można z różnicy objętości wnikającej wody i wyekstrahowanego gazu. Pomiary objętości przestworów międzykomórkowych wykonane na liściach z 13 rodzajów roślin potwierdzają możliwość przeprowadzania badań na roślinach o różnej budowie anatomicznej. 